\title{
BMJ Global Health Resilience and the struggle for medical research in Brazil
}

\author{
Lucas Leite Cunha, ${ }^{1,2}$ Luciana Bertocco de Paiva Haddad, ${ }^{3}$ Rachel Riera, ${ }^{2}$ \\ Laura Sterian Ward ${ }^{1}$
}

To cite: Cunha LL, Haddad LBdP, Riera $\mathrm{R}$, et al. Resilience and the struggle for medical research in Brazil. BMJ Glob Health 2018;3:e001070. doi:10.1136/ bmjgh-2018-001070

Handling editor Seye Abimbola

Received 23 July 2018

Revised 7 August 2018

Accepted 24 August 2018

\section{SLinked}

- https://doi.org/10.1136/ bmjgh-2018-000829

Check for updates

(c) Author(s) (or their employer(s)) 2018. Re-use permitted under CC BY-NC. No commercial re-use. See rights and permissions. Published by BMJ.

${ }^{1}$ Laboratory of Cancer Molecular Genetics, Faculdade de Ciências Médicas, Universidade de Campinas, São Paulo, Brazil ${ }^{2}$ Discipline of Evidence-Based Medicine, Department of Medicine, Escola Paulista de Medicina, Universidade Federal de São Paulo, São Paulo, Brazil ${ }^{3}$ Liver and Gastrointestinal Transplant Division, Department of Gastroenterology, Faculdade de Medicina, Universidade de São Paulo, São Paulo, Brazil

Correspondence to Dr Laura Sterian Ward; ward@fcm.unicamp.br
The global economic crisis that started in 2008 dramatically affected the investments in health system and also in science and technology. In this scenario, public budgets directed to innovation and research have helped to partially offset the decline in private science investments during the global economic turmoil. According to Organization for Economic Cooperation and Development (OECD) data, public supply for science and technology have stagnated, relative to gross domestic product, in most countries since 2011 due to the fading impact of stimulus packages and the simultaneous recovery in gross domestic product. ${ }^{1}$ In fact, the OECD reported that public investment in research and development remains below its pre-crisis status $(0.69 \%$ of gross domestic product in 2013 vs $0.76 \%$ in 2008) ${ }^{1}$ and the austerity taken by governments is fairly responsible for this statistic.

The Brazilian government did not take a different way. Recently, Massuda et al carefully performed a historical and critical analysis of the development of the United Health System (Sistema Único de Saúde, SUS) in Brazil. ${ }^{2}$ The authors highlighted the inseparable relationship between Brazilian economic and political crisis and obstacles to consolidation of the Universal Health Coverage in SUS. Indeed, the same austerity policies that have capped public expenditure growth and have threatened the sustainability of the Brazilian health system have also faded science and technology agenda.

The total amount of funding offered by the National Council for Scientific and Technological Development (CNPq) has declined over the last 3 years (figure 1). Additionally, in August 2017, the federal government conducted a contingency of $40 \%$ of the resource allocated through $\mathrm{CNPq}$ to the promotion of research. This cut of resources, which reached $\mathrm{R} \$ 523$ million (equivalent to US\$134 million), had a linear impact on all $\mathrm{CNPq}$ budget actions, including grants, development, hiring and governance. ${ }^{3}$ The
Summary box

The Brazilian Federal Constitution establishes that it is incumbent upon United Health System to promote scientific and technological development.

- Historically, Brazilian university hospitals are the core agents of three state policies: education, science and health.

- The total amount of the funding offered to medical research has declined over the las three years.

- The University Hospitals, most of them public, have accumulated debts in the last years of crushing that can jeopardize all the improvement of the hiring plan.

- Short-term consequences have been frightening with the return of many diseases such as yellow fever, measles and poliomyelitis.

Urgent measures should be taken by the authorities.

scientific production has sensed the austerity programme and the maintenance of the indicators is a demonstration of resilience.

The Brazilian Federal Constitution, in its article 200, item V, establishes that it is incumbent on SUS, among other tasks, to promote scientific and technological development, and university hospitals are deeply engaged in accomplishing this task. Historically, Brazilian university hospitals are the core agents of three state policies: education, science and health. Since the austerity programme has affected all these policies, and in consequence, university hospitals have been doubly beaten. As stated by Massuda et al, the consequences of a weakening primary healthcare service are evident, with citizens forgoing healthcare and in increased search of emergency services. This detracted the primary vocation of university hospitals of providing specialised assistance in a context of training health professionals and promoting science.

The university hospitals, most of them public, have accumulated debts in the last years of crushing that can jeopardise all the improvement of the hiring plan. Most of these hospitals are still unable to generate credit necessary to pay back wages. To this 


\section{Resilience of Medical Research in Brazil}

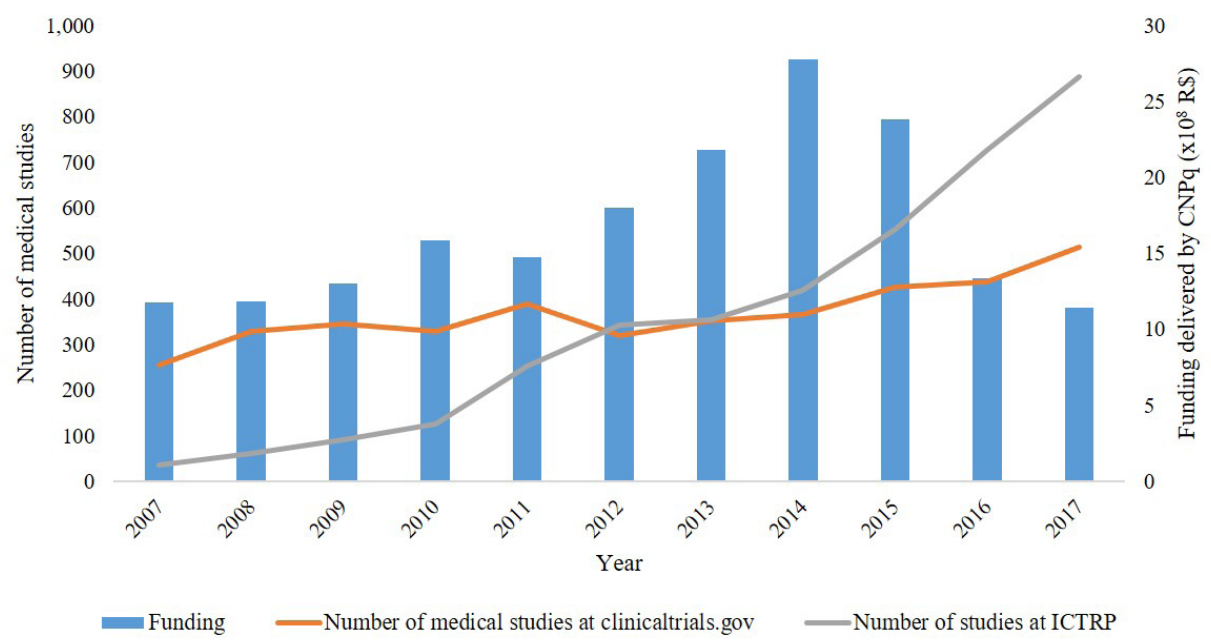

Figure 1 Resilience of medical research in Brazil over the last 10 years. Total funding delivered by the National Council for Scientific and Technological Development (CNPq) is expressed in bars and the total amount is seen in the right axis. Lines express the number of clinical studies obtained in online platforms, such as ClinicalTrials.gov ${ }^{6}$ (orange line) and International Clinical Trials Registry Platform ${ }^{7}$ (ICTRP, grey line).

problem should be added the low management flexibility, which has led these hospitals to be plunged into a governance crisis that makes excellence in education, research and healthcare an even longer path to be travelled. In addition, with accumulated debts and difficulties in the routine medical assistance, technological updating and productivity have been dismissed. However, the same resilience seen in healthcare also occurs in medical research. Indeed, even with the diminution of funding delivered by CNPq, the number of clinical trials registered in online platforms is persistently increasing, even if below their potential. It is possible that the austerity strategy of the government may result in consequences that can only be fully observed in the long term. In this sense, university hospitals may be at risk to become less attractive to the clinical trials market, reducing the competitiveness of medical research in Brazil.

Working in university hospitals is usually attractive for physicians since virtually all clinical physicians who reached chief positions are also successful researchers. ${ }^{4}$ Indeed, working at university hospitals has a career-enhancing effect mainly for senior physicians. ${ }^{5}$ This career peculiarity also occurs in Brazil. Most of the Brazilian university hospitals are linked to public medical schools, which are historically the concentrator of research expertise and whose entry process is most fierce. That is the reason why medical leaderships in Brazil are concerned that austerity strategy led by the government may undermine healthcare and also medical education, medical sciences and specialised medical assistance.

Short-term consequences have been frightening, with the return of many diseases such as yellow fever, measles and poliomyelitis. The country will have serious consequences in the medium term if urgent measures are not taken.
Acknowledgements The authors are grateful for the support of National Council for Scientific and Technological Development (CNPq).

Contributors LLC: conception and design, critical review of the literature and data, composition of the manuscript and final approval. LBdPH: design, critical review of the literature and data, composition of the manuscript and final approval. RR: design, critical review of the literature and data, composition of the manuscript and final approval. LSW: design, selection of notable articles for review, critical review of the literature and data, composition of the manuscript, clinical and translational orientation, and final approval.

Competing interests None declared.

Patient consent Not required.

Provenance and peer review Not commissioned; internally peer reviewed.

Data sharing statement № additional unpublished data from the study are available.

Open access This is an open access article distributed in accordance with the Creative Commons Attribution Non Commercial (CC BY-NC 4.0) license, which permits others to distribute, remix, adapt, build upon this work non-commercially, and license their derivative works on different terms, provided the original work is properly cited, appropriate credit is given, any changes made indicated, and the use is non-commercial. See: http://creativecommons.org/licenses/by-nc/4.0

\section{REFERENCES}

1. OECD Science. Technology Industry Outlook. 2014. Available from: http://dx.doi.org/10.1787/sti_outlook-2014-en [Accessed 20 Jul 2018].

2. Massuda A, Hone T, Leles FAG, et al. The Brazilian health system at crossroads: progress, crisis and resilience. BMJ Glob Health 2018;3:e000829.

3. CNPq. Relatório de Gestão exercício. 2017. Available from: http:// cnpq.br/documents/10157/6152175/Rel+Gest\%C3\%A3o+2017. pdf/209f5d96-66b0-4bf2-8bd8-2f9e9f40336f2018 [Accessed 20 Jul 2018].

4. Buddeberg-Fischer B, Stamm M, Buddeberg C, et al. Career-success scale-a new instrument to assess young physicians' academic career steps. BMC Health Serv Res 2008;8:

5. Degen C, Kuntz L. University hospitals as drivers of career success: an empirical study of the duration of promotion and promotion success of hospital physicians. BMC Med Educ 2014;14:

6. U.S. National Library of Medicine. ClinicalTrials.gov database. Available from: https://clinicaltrials.gov/ [Accessed 20 Jul 2018].

7. WHO. International Clinical Trials Registry Platform. Available from: http://www.who.int/ictrp/en/2018 [Accessed 20 Jul 2018]. 